\title{
Misinterpreting Japanese Student Collaboration in the L2 Classroom
}

\author{
Joshua Alexander Kidd \\ Kidd International \\ Utsunomiya University (EPUU)
}

In this study, I examined points arising in L2 English activities during which Japanese students resolved to collaborate with classmates. These points included moments when students were specifically instructed to work alone, were rebuked for collaborating, or both. Of issue here was that the value and meaning ascribed by the English native speaker (NS) teachers to Japanese students' spontaneous peer collaboration (SPC) reflected a prevailing assumption about L1 collaboration: that students were off task, were less proficient members of the class, or lacked motivation. The study explored the miscommunication that could result as students upheld what they viewed as an acceptable classroom behaviour, namely peer support through verbal collaboration, while simultaneously attempting to gain teacher recognition as competent and engaged members of the class. Candid student insights illustrated that during language-learning activities students should be given greater freedom to collaborate when and with whom they desire without fear that this will negatively impact how their performance is perceived by the instructor.

本研究は、日本人生徒が英語でのL2活動中に他のクラスメイトと協力しようとする時に生じる 問題点を考察する。対象となる場面は、個人で活動するように事前に指導を受けた場合、他の 生徒と協力しようとし注意された場合、その両方の場合である。ここでの問題は、日本人生徒が 授業中に自発的にピア・コラボレーション(SPC)することに関し、英語母語話者(NS)の教師は、母 語での共同作業では生徒は集中せず、生徒のクラス内での能力は低く、モチベーションがない と判断してしまうことだ。この研究では、生徒がクラスルーム内で許される行為だと思う事をする 事によって起こるミスコミュニケーションを扱う。これらのミスコミュニケーションは、生徒が自分 は有能で真剣に取り組んでいるという事を先生に理解してもらおうとすると共に、言葉を通じて

JALT Journal, Vol. 39, No. 2, November 2017 
協力することで得られる生徒間のサポートに関してである。生徒の率直な意見からは、外国語を 勉強する為の活動中は、先生にマイナス評価をされる心配なく、生徒は自由にいつでも誰とでも 協力できるべきと感じていることが分かった。

$\mathrm{F}$ or the language teacher working across cultures it can be challenging to avoid unintentionally imposing pragmatic expectations on students, given that aspects of one's own culture and how these are manifested in the classroom are not always identifiable. Unfamiliar pragmatic expectations with regard to the production and interpretation of language in the classroom can be confusing and disorienting for students when there are culturally different perceptions of what constitutes classroom appropriateness. An obstacle to identifying the motivations behind pragmatic norms lies in the very fact that divergence between the L1 and L2 may not be observable, unless of course violations of these assumed norms interfere with communicative objectives. Recognising variance in pragmatic norms and avoiding cross-cultural misunderstanding is complicated by the fact that the teacher is informed by background, experiences, beliefs, and professional knowledge that may not always be compatible with student expectations (see Borg, 2006, and Ishihara \& Cohen, 2010, for discussion of teacher education and beliefs). Moreover, in the cross-cultural classroom, we can assume that there are certain shared patterns by which students express themselves, interact, interpret language, and behave that do not always align with the knowledge and schematic framework that teachers bring to the classroom (Archer, Aijmer, \& Wichmann, 2012).

Building on a previous proposal that there may be differences between what teachers and their students consider to be standard and conventionally acceptable language use and behaviour (Kidd, 2016), in this study the role of student-initiated spontaneous L1 collaboration in the L2 classroom was explored. Given that L1 collaborative exchanges serve key functions in SLA (Bao \& Du, 2015; Swain, Brooks, \& Tocalli-Beller, 2002), awareness of potential differences in pragmatic dimensions of collaboration as performed and interpreted during L2 activities can enable teachers to avoid ascribing their own perceptions of appropriateness and better predict points of possible cross-cultural misunderstandings. To this end, English native speaker (NS) teachers' interpretations of their Japanese students' L1 collaborative exchanges with peers during L2 activities were examined and compared with students' reflections on their own collaborative language use. The next three sections present a brief introduction to pragmatic variance, an overview of L1 use in the L2 classroom, and a working description of spontaneous peer collaboration. The fifth section outlines the research methodology 
and introduces the participants and setting. The sixth and seventh sections consist of an analysis of student collaboration as revealed through teacher and student feedback. The article concludes with a discussion of the potential pedagogical applications in the L2 classroom.

\section{Cross-Cultural Pragmatic Variation in the L2 Classroom}

An issue that many language teachers will frequently encounter during L2 activities is that their students initiate L1 oral exchanges with classmates. Student collaboration in the mother tongue challenges the teacher not only to consider cognitive and social aspects of the L1 in L2 acquisition but also to determine whether or not students require guidelines outlining when and for what purposes the L1 should be collaboratively employed. As the balance of power in the classroom typically favours the teacher, opportunities for students to express their views on L1 use tend to be limited. Consequently, it can be challenging for students to harness a range of L1 pragmatic and sociolinguistic abilities associated with collaboration. Assumptions as to the appropriateness of collaborative L1 exchanges are primarily determined by the teacher and may not always be consistent with those upheld and valued by students. Despite acknowledging the potential for cross-cultural variation, even the experienced and well-intentioned teacher is likely at times to misinterpret student motivations and interactive objectives at times when students collaborate with peers.

The pragmatic rules for language use, as Bardovi-Harlig and MahanTaylor (2003) observed, "are often subconscious, and even native speakers are often unaware of pragmatic rules until they are broken (and feelings are hurt or offense is taken)" (p. 1). Culturally informed expectations of communicative norms operate on all levels and inform verbal and nonverbal interactional practices employed to achieve goals such as upholding rank and role while avoiding imposition in a given situation. Noting the potential for divergence in pragmatic forms, Archer et al. (2012) argued, "A problem that arises frequently in interaction between people of different cultures is that one participant or group is perceived by the other to be impolite" (p. 110). The meaning teachers assign to their students' linguistic behaviour in collaborative exchanges is shaped by factors that are so ingrained that they are not always known or evident to the individual.

The notion of culture of learning draws attention to "the often implicit values, expectations and interpretations of learning and teaching which frame ideas and pedagogic practices" (Jin \& Cortazzi, 2011, p. 114). These socially transmitted values associated with expectations of educational practices in- 
fluence pedagogic practices and shape notions regarding "good" teacher and student classroom performances. Teachers' knowledge of their own teaching practices, the result of their own learning and teaching experiences, is embedded in their practices and attitudes towards themselves and their students. These notions are manifest in attitudes pertaining to areas such as rank, roles, and classroom expectations and to broader issues such as the objectives of education. Recognising the potential for variance in pragmatic norms requires a level of awareness of social norms, cultural reasoning, and the impact of language on the interlocutor (Ishihara \& Cohen, 2010). Points of disparity regarding the pragmatic norms by which students and their teachers view L1 collaboration in terms of classroom appropriateness and communicative objectives can give rise to incompatible expectations and interpretations of classroom collaborative practices.

\section{L1 Use in the L2 Classroom}

The role of students' native language in the classroom by the teacher, the students, or both remains a topic of debate among researchers. The position that a monolingual approach facilitates L2 acquisition borrows from claims that the quantity of exposure is critical and informs the view that the target language should be the only language allowed in the classroom. Challenging this premise, a large number of researchers have argued that the L1 provides considerable benefits such as lowering the affective filter, making input more comprehensible, connecting with the students' identity, and creating better understanding of tasks to ensure successful task completion (see Butzkamm \& Caldwell, 2009; Levine, 2003; Meyer, 2008; Turnbull \& Dailey-O'Cain, 2009).

Arguments calling for a compromise promote a language-learning context that does not deny the value of either the learners' L1 or the L2. A controlled approach to the L1 as a temporary measure for rendering the L2 comprehensible found support from Butzkamm (2003) who argued that "with growing proficiency in the foreign language, the use of the MT [mother tongue] becomes largely redundant and the FL [foreign language] will stand on its own two feet" (p. 36). Similarly, Meyer (2008) made the case that it is critical to maximise the L2 and the "L1's primary role is to supply scaffolding to lower affective filters by making the $\mathrm{L} 2$ and the classroom environment comprehensible" (p. 157). Advocates targeting this middle-ground position have argued that the L1 promotes distinct cognitive advantages when judiciously employed in the language classroom. 
Stressing that the use of the L1 is commonplace, Bao and Du (2015) argued, "L1 use should be acknowledged as an instinctive process that can facilitate learners' involvement in verbal interactional processes" (p. 19). Recognising and embracing the social and cognitive functions of the L1 are not only pedagogically sound but are also critical to establishing and upholding culturally inclusive L2 teaching practices that embrace student identities. Research has demonstrated that learner identity is intrinsically associated with the process of language learning (Block, 2007; Norton, 2013). The language classroom, as a setting for identity construction, can impose restrictions on the learners as they seek to align or not with the kinds of identities made available by the teacher. Given learners' awareness of their cultural and social identities in language use, creating a place for the L1 in the classroom not only carries pedagogic benefits but also sends a message to students that they can position themselves and modify or align with multiple identities. This relationship between language learning and identity was framed by Norton and Toohey (2002) as follows:

Language learning engages the identities of students because language itself is not only a linguistic system of signs and symbols; it is also a complex social practice in which the value and meaning ascribed to an utterance are determined in part by the value and meaning ascribed to the person who speaks. (p. 115)

Given that research has identified ways in which L1 use can serve as an effective social and cognitive tool to facilitate L2 acquisition and that L1 use is closely tied to culture and identity, the question is no longer whether L1 use should be included in language classrooms. Rather, what is required now is the identification of how much, in what situations, and for what functions the L1 can be efficiently and meaningfully employed.

\section{Spontaneous Peer Collaboration}

L2 learning studies examining collaboration and the social nature of learning have drawn extensively on the framework of sociocultural theory (SCT), which regards cognition and knowledge as constructed through social interaction (Lantolf, 2000; Morita, 2000; Ohta, 2000). Implicit in this notion is the position that language itself is not only the learning objective but also a mediated means to achieve this goal. Language acquisition is viewed not as an individual endeavour but rather as a collaborative process that en- 
hances learners' abilities to acquire higher order functions through various socially mediated activities. Bao and Du (2015) underscored that "through speaking, we mediate our reasoning process, alter our ways of thinking, and develop a mutual understanding of the communicated information in order for us to act and solve problems" (p. 13). Spontaneous collaboration, as a cognitive tool that creates a social space where learners support each other through scaffolding, enables learners to perform as experts and novices in solving problems and co-constructing knowledge. Swain (2000) explained collaborative dialogue as a process of engagement in problem solving and knowledge building in which "language use and language learning can cooccur. It is language use mediating language learning. It is cognitive activity and it is social activity" (p. 97). Collaboration with peers provides learning opportunities not only for novice learners, but more proficient learners can also benefit from the dialogic interaction given that learners' status over a series of interactions is fluid rather than fixed (Donato, 1994).

The term spontaneous peer collaboration (SPC) is used to delineate situations in which students engage classmates, primarily in the L1, with the intention of negotiating meaning through soliciting, transmitting, or corroborating information related to the L2 learning task (Kidd, 2016). These moments are differentiated from points during L2 activities when students are directed by the teacher to work with peers such as in pair- or groupwork activities. The point of differentiation is that students, not the teacher, claim control of the exchange timing, content, turn taking, and choice of interlocutors. Foster and Ohta's (2005) investigation of classroom negotiation illustrated that students actively sought peer co-construction and prompting when engaged in classroom tasks. The researchers surmised that "students expressed interest and encouragement while seeking and providing assistance and initiating self-repair of their own utterances, all in the absence of communication breakdowns" (p. 402). The findings suggest that upholding supportive discourse was prioritised by students over achieving entirely comprehensible input.

An increasing number of L2 studies drawing on SCT have demonstrated that meaning derived through language use within the social context plays an important role in language learning (Kobayashi, 2003; Lantolf, 2000; Morita, 2000; Ohta, 2000; Swain, Brooks, \& Tocalli-Beller, 2002). Among other things, SCT holds that learning ensues in various places and forms and that students bring their own cultural, social, and individual frames of reference to their interactions. Although SCT has shed light on peer interaction and implications for L2 learning and teaching, there has been little attention 
to the communicative intentions associated with spontaneous peer L1 collaborative exchanges initiated by students in the L2 classroom context and the implications of such SPC for L2 learning and teaching.

\section{Method}

\section{Purpose of the Study}

This study focused on Japanese L2 English learners' L1 interaction while engaging in spontaneous collaborative exchanges with peers (in which they were not assigned roles by the teacher). The researcher investigated how the learners interpreted their interactive peer exchanges and how they felt these exchanges were being interpreted by the teacher. The study was aimed at identifying when and for what purposes the students collaborated with peers during L2 activities. The students' subjective interpretations of their own language use and behaviour were examined with attention to the teachers' interpretations of student collaboration and with a view to identifying points of cross-cultural pragmatic disparity that interfered with learning and identity alignment.

\section{Participants and Setting}

The participants were a class of 40 Japanese students aged 18 to 22 (34 women and 6 men) attending a 3-year nursing college. The college is located in a small rural town and attached to a rapidly expanding hospital complex where students engage in clinical practice and are employed following graduation. Six rows of precisely positioned desks face a lectern, whiteboard, and screen. Students are assigned desks for the semester and, with the exception of clinical visits and lunch, spend the majority of their day in the classroom with different subject teachers visiting. The desks are not fixed, making it possible for teachers to adopt varying configurations to facilitate pair- or group-work activities when desired. As part of course requirements, students are required to complete an English speaking and listening program convened twice weekly and instructed by part-time NS teachers over the 15-week semester.

\section{Design and Data Collection}

Conducted over a 4-week period, the study focused on incidents of SPC from the perspectives of four NS teachers and their students. (See Table 1 for teacher information.) Data were collected from the following sources: video 
recordings of classroom interaction, researcher observations of English classes, teacher focus group discussion sessions, and retrospective student interviews. To collect samples of the students' collaborative exchanges, the students agreed to have two video cameras placed on either side of the classroom. All participants self-selected and pseudonyms have been used throughout to afford anonymity.

Table 1. Teacher Information

\begin{tabular}{lccccc}
\hline Teacher & $\begin{array}{c}\text { Sex / } \\
\text { age }\end{array}$ & $\begin{array}{c}\text { Country } \\
\text { of origin }\end{array}$ & $\begin{array}{c}\text { Teaching } \\
\text { qualification }\end{array}$ & $\begin{array}{c}\text { Years teach- } \\
\text { ing in Japan }\end{array}$ & $\begin{array}{c}\text { Level } \\
\text { taught }\end{array}$ \\
\hline Haley & F / 45 & U.S.A. & MA TESOL & 15 & 2nd \\
Kerrie & F / 42 & U.S.A. & MA TESOL & 11 & 2nd \\
Michael & M / 54 & U.K. & MA TESOL & 19 & 1 st \\
Randal & M / 43 & Australia & MA TESOL & 12 & 1 st \\
\hline
\end{tabular}

Following English activities, classroom video recordings were viewed and points during which the students initiated verbal exchanges with classmates were identified and logged for explication in retrospective interviews. Logged episodes were employed as visual stimuli and students were encouraged to share their attitudes towards their own behaviour and language use (see Gass \& Mackey, 2000; Mackey \& Gass, 2005). Students were shown 24 episodes of collaborative peer exchanges that occurred during L2 activities:

- 5 cases -individual student was asked by teacher to answer a question,

- 5 cases - teacher explained learning activity to whole class,

- 4 cases-students did a reading comprehension activity,

- 4 cases-teacher directed a correction,

- 3 cases-students did CD listening activity, and

- 3 cases-teacher explained vocabulary or grammatical structures.

Data were segmented and labelled with in vivo codes, and recurring patterns of student attitudes, behaviour, and shared language use were identified. Students' subjective insights into their own language discourse and behaviour during collaborative exchanges were examined with attention to the use of peer collaboration as a means to avert error, avoid monopolising teacher time, and facilitate comprehension (see Kidd, 2016). Examples of participant feedback representative of the findings are presented to illustrate internal connections in the data. 


\section{Stimulated Recall}

Stimulated recall (SR), an introspective method of data collection in which one is prompted via visual or oral stimulus, encourages participants to recall and report on thoughts and motivations entertained while engaged in specific activities or tasks. Based on the view that one can be encouraged by a visual reminder to recall thoughts one has had while performing a recently accomplished task, SR methodology provides access to the link between discourse and cognition (Dörnyei, 2007). Verbal reports, conducted soon after L2 activities to reduce potential memory loss due to time lapse, have been employed by researchers to reconstruct the psycholinguistic processes of speakers through the aid of stimulus (Cohen, 2004). Tangible stimulus is regarded as a means by which to "stimulate recall of the mental processes in operation during the event itself." Thereby "access to memory structures is enhanced" (Gass \& Mackey, 2000, p. 17) without placing the same demands on memory retrieval as post hoc interviews or think-aloud protocols that require extensive training of participants (Gass \& Mackey, 2000, p. 18). By examining verbal report data, researchers seek to understand "what the respondents actually perceived about each situation (e.g., what they perceived about the relative role status of the interlocutors) and how their perceptions influenced their responses" (Cohen, 2004, p. 321).

Given that the emphasis is on the recollection of retrievable information rather than rationalisation, SR is a useful research tool for observing the connection between discourse and cognition in the classroom (Keyes, 2000; Plaut, 2006; Sime, 2006; Yoshida, 2008). Although an advantage of SR is that tangible stimulus enhances recall while minimising demands on memory retrieval, there is nevertheless a need to triangulate with observable classroom data to increase validity and reliability, because if cognitive processing is unconscious, then internal processes may be inaccessible or susceptible to erroneous reporting (Dörnyei, 2007).

\section{Results: Teacher Insights}

The following section presents the teachers' views of their students' L1 collaboration as revealed in focus group discussions during which classroom recordings were viewed. The teachers' observations are examined with attention to three themes: collaboration as an indication that students were (a) off task, (b) struggling with content, or (c) interfering with the teachers' desire to assist learners. 


\section{Teacher Reflections on Student Collaboration}

Teacher feedback illustrated that in many, though not all, cases SPC was negatively viewed by teachers as it was associated with behaviours determined to be inappropriate and counterproductive to their teaching and learning objectives in the L2 classroom. For example, teachers reacted critically to situations when an individual student was nominated to answer a question and then proceeded to consult a classmate prior to venturing a response. In addition, SPC was cited by the teachers as interfering with their abilities to meet lesson objectives and to assess student comprehension of content. In 17 of the 24 cases, the teachers indicated that they felt collaboration was inappropriate as the learning task warranted independent student participation. When asked how they would have preferred students to respond, the teachers responded that they wanted to be directly petitioned for help in order to make available the appropriate instructional support.

Participating teachers indicated that they had intermediate to advanced Japanese proficiency and were confident that they could understand the content of student exchanges. Given the timing and content of SPC, the teachers expressed the view that direct intervention to limit or prevent collaboration was necessary and appropriate when students were expected to work independently. Intervention was typically a direct demand for the students to "work alone," stated in both Japanese and English. As explanation, teacher Michael commented, "There are opportunities for group and pair work, but there are times we need students to work alone. I don't expect students to work alone all of the time, but there are definitely times when they need to." Asked when individual participation was viewed as a requirement, Michael responded, "There are many situations; I'd say assessment, examinations, homework, listening ... basically the activities when I need to gauge who does or doesn't understand." Instructor Kerrie added, "It's disrespectful to turn and ask someone for help when asked a question. If you don't know just tell me and I will help. That's why I'm here." Kerrie further explained, "It's embarrassing when I'm standing there watching the whole thing unfold. I might ask a question and the student just turns away and asks another student. I'm directly in front watching and waiting till they're done. It's really rude."

\section{Teacher Assumption 1: Collaboration Indicates Students Are Off Task}

Drawing on their professional experiences in the classroom, the teachers commented that peer exchanges often did not relate to the content of lessons and represented an unwelcome distraction that needed to be closely 
monitored and discouraged. Kerrie noted, "It's impossible to progress with the lesson when students aren't paying attention or half listening because it takes so much longer to understand the content." Teacher Randal reflected, "It's critical to keep control to make sure everyone's focused"; and Haley added, "If it ends up being a chat, maybe about what was on TV last night, it can quickly escalate. It's hard to get back to the lesson." Haley underscored that the teachers were not always opposed to collaboration: "I don't think that any of us are against students having a quick word from time to time in Japanese. It's just that students need to be focused during activities to get the most out of them."

Although teacher concern that student L1 talk is off task and counterproductive to L2 acquisition is not uncommon, research has found that this assumption is far from conclusive (see Bao \& Du, 2015; Carless, 2007; Swain \& Lapkin, 2000). Swain and Lapkin's (2000) examination of L1 use by grade 8 French immersion students found that contrary to their teachers' expectations, only $12 \%$ of L1 interaction was off-task talk. The L1 was found to serve critical cognitive and social functions, leading the researchers to conclude that "to insist that no use be made of the L1 in carrying out tasks that are both linguistically and cognitively complex is to deny the use of an important cognitive tool" (pp. 268-9). Algería de la Colina and del Pilar García Mayo's (2009) examination of undergraduate EFL learners L1 use while engaged in collaborative tasks found little to no off-task behaviour, leading to the conclusion that "the use of the L1 in the L2 classroom does not mean lack of involvement in the tasks" (p. 342). The researchers stressed that the L1 functioned as a cognitive tool by which students could access L2 forms, focus attention, and retain semantic meaning. These findings are consistent with the results reported by Bao and Du (2015), which revealed only $4 \%$ off-task L1 use by students learning Chinese. Among other things, data illustrated that the L1 provided essential cognitive support in clarifying task content, establishing goals, and assessing L2 grammatical forms.

\section{Teacher Assumption 2: Collaboration Denotes L2 Limitations}

Teacher feedback suggested that SPC was assumed to flag a less competent or unmotivated member of the class seeking the assistance of a capable classmate, the assumption here being that this alliance would enable the weaker student to bridge comprehension difficulties, avoid "hard work," or both. In Michael's words: "It's a response to the level of difficulty. If they don't know the answer some students just ask a classmate. It's much easier when you have a friend to ask." This view was upheld by Randal who com- 
mented, "I think that it can be a way to cope for those students who don't really want to be studying or struggle ... or perhaps those who are a little bit lazy." Asked how they responded to SPC when it was assumed to be an issue of L2 comprehension, Randal responded, "I say something like, 'If you don't know that's fine, that's part of learning. Always ask me because the question you have is probably something other students want to know too."' Kerrie indicated that when the student soliciting assistance was viewed as struggling with lesson content, yet failing to commit the effort she expected, her approach was to say something like, "I really do expect more effort from you. It's disappointing when you're not doing your best." The teacher further commented, "This approach can encourage students to take on responsibility for their behaviour in class."

\section{Teacher Assumption 3: Collaboration Undermines Teacher Role and Rank}

Randal voiced concern that by drawing on classmates, students interfered with his ability to aid them in the way he desired: "It makes it hard to do my job because there's no chance to identify the problem or include supplementary instruction." This sentiment was backed by Kerrie, who noted, "It's a waste not to ask me when I'm right here. I want to help out." Alluding to the threat to professional standing, Haley commented, "It's rude to ignore me and ask a student. I say something to let the student know I want to be asked." She further illuminated, "It sends the wrong kind of message to the other students if you let it go." Asked to elaborate what this message was, she explained, "Basically that we aren't here to help. We aren't really needed. Maybe they're better off asking classmates who speak Japanese." The teachers interpreted student collaboration as undermining their ability to instruct and thereby undermining their professional identities.

\section{Result: Student Insights}

In this section, the students' insights into their own spontaneous L1 peer exchanges are considered as a means to (a) avert errors, (b) avoid monopolising teacher time, and (c) facilitate comprehension through peer knowledge and jointly constructed performance.

\section{Student Reflections on Peer Collaboration}

Classroom recordings revealed that a distinctive feature of SPC was that students initiated exchanges with classmates irrespective of whether or 
not they were being directly observed by the teacher. Students were aware of the teachers' negative views of collaboration, and this was a source of frustration leading to critical feelings towards both the teacher and the L2. Nevertheless, asked whether teacher intervention deterred her from collaborating, student Miho stated that it would do so, but only temporarily. Feedback from student Kanako suggested that collaboration was viewed as an acceptable and standard classroom behaviour that, among other things, facilitated participation and enhanced confidence: “私は答えをいう前にクラス メイトと答えを確認したい。友達と確認できると、もつと自信をもてる気がする。少しリ ラックスできる感じがする” [I want to check my answers with classmates before I answer. I think I can feel more confident if I can check with my friends. It's like I can relax a little]. Students disputed the inference that collaboration represented a violation of classroom practices, suggesting that it was a means by which to avert errors, manage risk, avoid monopolising teacher time, and seek confirmation.

An important point to consider is that the participants were 1st-year students; they were making the transition from 50-minute high school English classes taught by Japanese teachers primarily in the L1 to an English program with 90-minute classes instructed by NS teachers primarily in the L2. An important consequence of dependence on the L1 in English lessons at the junior and senior high school levels is that students have been conditioned to rely on L1 support to understand L2 content (Stephens, 2006). Consequently, students may presume that they have not comprehended a concept unless it is accompanied by Japanese and perceive exclusive use of the target language as "a violation of the known classroom culture" (Burden, 2001, p. 5).

\section{Student Insight 1: Collaboration to Avert Error and Manage Risk}

SPC was a means by which students dealt with potential anxiety associated with errors committed in front of the teacher and classmates. In student Miho’s words: “もし間違えたら、みんなが私の事をバカだと思うのが心配” [If I make a mistake, I'm worried that everyone will think that I'm stupid]. Similarly, Kanako commented, “間違えたら、恥ずかしいから本当に間違えたくない” [I really don't want to make a mistake because it's embarrassing]. Nakane's (2006) examination of intercultural communication between Japanese university students and NS lecturers found that students consider speaking in front of the class potentially embarrassing and view it as a "big deal." Similarly, Kidd's (2016) examination of Japanese students' L2 classroom interaction found that speaking in front of the class was regarded as a significant threat 
to face, often mitigated through collaboration and joint student responses.

The potential threat to face (Brown \& Levinson, 1978) is compounded if students are unfamiliar with L2 course demands and lack rapport with classmates and the teacher. In addition, Nation (2003) noted that "using the L2 can be a source of embarrassment particularly for shy learners and those who feel they are not very proficient in the L2" (p. 2). Tani's (2008) examination of Asian university students' participation found that "low levels of in-class participation from Asian students are mostly caused by anxiety and fear of making mistakes in public rather than individual characteristics or learning approaches" (p. 351). The implication that fear of error is taken seriously and risks are managed in part by soliciting classmates prior to venturing a contribution is illustrated in the student feedback: “みんなの前 で間違えることが大嫌いなので私は美保と答えについて話していた。もしも私がみん なの前で間違えたら、私が頭悪いということがみんなにばれてしまうと感じる” [I was talking to Miho about the answer because I hate making mistakes in front of everyone. If I make a mistake I feel like everyone will discover I'm stupid].

\section{Student Insight 2: Collaboration to Avoid Monopolising Teacher Time}

Collaboration was employed to avoid monopolising the teacher's time and potentially interfering with classmates' opportunities for instruction. Moreover, students expressed concern that individual attempts to confirm material or seek comprehension would restrict class progress. Kanako indicated that she was anxious to avoid questions of little relevance to her classmates: “先 生が忙しいのは分かってるから、先生に時間をとらせたくない。他の生徒は答えをもう 分かってるかもしれないから私が授業の時間を使って聞いたらみんなに平等じゃない” [I know the teacher is busy so I don't want to use his time. Other students might already know the answer so it's not really fair if I use the class time to ask]. Similarly, student Kotomi commented, “先生がそのままレッスンを続けられ るように、クラスメイトに聞くのが一番だと思う” [I think it’s best if I ask classmates so that the teacher can continue with the lesson]. In this way, collaboration enabled students to avoid monopolising teacher time when comprehension difficulties were felt not to be shared.

Kotomi explained that she determined whether to consult the teacher based on the amount of time she assumed a teacher response would require: “もし小さい事で先生がすぐ直せる事なら先生に聞いてもいいけど、時間がか かるって分かってて私だけの為の事なら聞かない” [If it's a small thing that the teacher can fix quickly then I don't mind asking the teacher, but if I know it's going to take time and it's just for me then I won't ask]. Student Shunsuke commented that “何か大切な事だったら、授業後先生に聞く” [If it’s something 
important then I ask the teacher after class]. Shunsuke's willingness to approach the teacher after class suggests that collaboration was not intended to conceal comprehension difficulties but rather was an accessible means by which to resource class knowledge in reciprocal exchanges without imposing on the teacher or obstructing progress.

\section{Student Insight 3: Collaboration to Facilitate L2 Comprehension}

Confirmation of lesson content through peer collaboration was cited by students as a standard classroom practice. Kanako commented, “私にとって 分からない事をクラスメイトと話すのは普通。私はそうやって学ぶから” [It’s usual to talk about the things I don't know with classmates. That's how I learn]. Foster and Ohta's (2005) examination of classroom negotiation found that students actively assisted each other to conduct tasks through co-construction and prompting, noting that "learners expressed interest and encouragement while seeking and providing assistance and initiating self-repair of their own utterances, all in the absence of communication breakdowns" (p. 402). In support of this position, Kidd (2016) found that Japanese students employed collaborative exchanges to ascertain solutions to challenging content and to collectively generate ideas. Students did not regard exchanges as a less competent student soliciting information from a more competent peer but rather as mutually beneficial.

When teacher intervention blocked student collaborative efforts, this undermined expectations of classroom appropriateness, leaving students feeling frustrated and without a viable means to establish comprehension. In Shunsuke’s words: “私たちが質問について話しているだけなのに、先生はそれ をなんで止めようとしたのか分からない” [I really don't know why the teacher tried to stop us when we were just talking about the question]. Illustrating the importance of L1 collaborative exchanges, Algería de la Colina and del Pilar García Mayo (2009) found that it provided university students with essential cognitive support through enabling access to L2 forms, focusing attention, retaining semantic meaning, and creating new meaning in the L2. In the current study, students recognised the value of collaboration as a mediating tool to confirm content and to mitigate communication apprehension by allowing students to check their ideas: “私の答えが正しいと思うか私は陽人 に聞いていた。私たちは普段お互いと確認をする。時々彼は分からないときがあるけ ぞ、それは関係ない。それでも一応彼に聞いておきたいだけである” [I was asking Haruto if he thought my answer was correct. We usually check with each other. Sometimes he doesn't know but that doesn't really matter. I just want to ask him anyway]. Peer assistance could be harnessed without concern 
that revealing comprehension difficulties would have a negative impact on how one was perceived by classmates.

\section{Discussion}

The study draws attention to differing interpretations of the cultural and situational appropriateness of student collaboration during L2 activities as viewed by NS teachers and their Japanese students. Differing views of SPC are of interest given that the content and motivations behind exchanges revealed cross-cultural inconsistencies in the functions of SPC and how these exchanges were interpreted. Although the teachers assumed SPC was a sign of comprehension difficulties, students indicated that collaboration enabled them to negotiate class material. Therefore, SPC was not an off-task behaviour but rather an indication that students were proactively endeavouring to mitigate face threat associated with an errant response, avoid monopolising teacher time, and seek confirmation. In addition, students' collaborative practices suggested that independent student contributions were not viewed as being more meaningful than those proffered through joint efforts. When teachers intervened to prevent collaboration or chastise the initiator, this placed constraints on student interaction and resulted in student uncertainty, frustration, and reluctance to engage in L2 activities. Of importance here is that, in contrast with the teacher, students did not regard collaboration as a competent student assisting a less able peer but rather as a reciprocal process that was advantageous to all those participating.

Kidd's (2016) examination of Japanese students' reflections on L2 activities found that students regarded soliciting answers from peers as appropriate in the classroom and consequently did not feel the need to conceal collaboration from the teacher. Teacher intervention reinforced that collaboration not sanctioned by the teacher was regarded as a violation of acceptable classroom practices and behaviour irrespective of whether it contradicted student expectations. Although the teachers may not have intended the directive to work independently as an imposition, from the students' perspective individual contributions were interpreted as restrictive, threatening, and inconsistent with views of standard classroom practice. Given that the teacher tends to determine permissible classroom behaviour and language practices, collaborative exchanges that fell outside of assumed standards were restricted and met with a negative teacher appraisal.

The students valued collaboration as a means by which to process input, modify output, manage anxiety, and prepare to speak in front of the class. Students employed collaboration to check responses, examine different 
perspectives, acquire knowledge, exercise ownership of their learning, and build affective bonds. Among other things, through collaborative negotiations, "problem utterances are checked, repeated, clarified, or modified in some way (lexically, phonologically, morphosyntactically) so that they are brought within the optimum i+1 level" (Foster \& Ohta, 2005, p. 405). In addition, research has demonstrated cognitive advantages of collaborative learning associated with activities such as "engaging with the task, trying to understand other people's thinking, explaining and justifying one's own thinking, critically monitoring what others are doing, and being supported in carrying out complex tasks" (Barnes, 2004, p. 14). Blocking collaboration was seen by students as threatening, restrictive, and inconsistent with what students considered standard classroom practice.

\section{Towards the Collaborative L2 Classroom}

In the collaborative classroom, students are encouraged to enact cultural identities, and the legitimacy of peer co-construction is upheld as a valuable linguistic practice. Teachers' restricting or blocking L1 collaboration lowers student motivation and morale and may be interpreted by students as the rejection of the students' classroom culture and language. To avoid such a situation, teachers are encouraged to recognise that L1 collaborative exchanges serve as a passage through which students actively work together to build and maintain affective bonds, mediate task completion, assist each other, co-construct knowledge, and solve problems. In addition, research illustrates that L1 exchanges provide learners with cognitive support to accomplish tasks that they may not be able to achieve without using the L1 (Bao \& Du, 2015; Swain \& Lapkin, 2000).

Japanese students' predilection for L1 peer collaboration presents a platform from which the teacher can foster and enhance L2 collaboration skills and facilitate learning. To this end, collaboration should be explicitly valued as an instructional goal, and students should be provided appropriate opportunities to collaborate in the L1, while at the same time given appropriate language support and opportunities to develop and strengthen their L2 collaborative skills. Teachers are encouraged to incorporate explicit L2 instruction targeting collaborative practices such as taking turns, asking questions, confirming understanding, paraphrasing, elaborating and providing feedback on peers' ideas, negotiating responsibilities and goals, and handling disagreements. These skills can be employed when students work together in the L2 to discuss activities, negotiate meaning, clarify understanding, and communicate their views. In this way, collaborative activities 
should be maximised whenever possible not only to enrich the classroom experience but also to bridge the gap between L2 use in and outside of the classroom by preparing students to use the target language with varying interlocutors in a range of collaborative configurations.

\section{Conclusion}

Miscommunication can result when Japanese students uphold what they view as acceptable classroom behaviour, namely peer collaboration, while simultaneously attempting to gain teacher recognition as competent and engaged members of the class. This study has illustrated that in the L2 classroom, even experienced NS teachers' assumptions regarding the motivations and communicative objectives behind their Japanese students' L1 collaborative choices can result in critical and inaccurate evaluations of their students. The participating teachers felt confronted when students engaged peers after being directly called on by the teacher and interpreted SPC as an indication that students were off task, had limited L2 competence, or lacked motivation. The value and meaning ascribed to SPC failed to account for the fact that from the students' perspective, collaboration was seen as an acceptable interactional practice by which group knowledge was shared while minimising the threat to an individual's face. For the students, L1 collaboration served as a social and cognitive tool by which they engaged in reciprocal exchanges to solve problems and co-construct meaning while at the same time upholding affective peer bonds. The study highlights the need for teachers to reflect on their assumptions of SPC and to employ and promote culturally sensitive teaching and learning strategies that acknowledge and embrace diverse communicative practices.

Joshua Kidd holds a PhD in applied linguistics from Macquarie University, Sydney. He runs his own language school and is a part-time lecturer in the English Program of Utsunomiya University. His research interests include pragmatics, identity, and teacher education. He recently published Face and Enactment of Identities in the L2 Classroom with Multilingual Matters.

\section{References}

Algería de la Colina, A., \& del Pilar García Mayo, M. (2009). Oral interaction in taskbased EFL learning: The use of the L1 as a cognitive tool. International Review of Applied Linguistics in Language Teaching, 47, 325-345. https://doi.org/10.1515/iral.2009.014 
Archer, D., Aijmer, K., \& Wichmann, A. (2012). Pragmatics: An advanced resource book for students. London, England: Routledge.

Bao, R., \& Du, X. (2015). Learners' L1 use in a task-based classroom: Learning Chinese as a foreign language from a sociocultural perspective. Journal of Language Teaching and Research, 6, 12-20. https://doi.org/10.17507/jltr.0601.02

Bardovi-Harlig, K., \& Mahan-Taylor, R. (2003). Teaching pragmatics. Washington, DC: Office of English Programs, U.S. Department of State. Retrieved from https://americanenglish.state.gov/files/ae/resource_files/03-41-3-h.pdf

Barnes, M. (2004, November-December). The use of positioning theory in studying student participation in collaborative learning activities. Paper presented at the Annual Meeting of the Australian Association for Research in Education, Melbourne, Australia. Retrieved from http://www.aare.edu.au/

Block, D. (2007). The rise of identity in SLA research, post Firth and Wagner (1997). The Modern Language Journal, 91, 863-876. https://doi.org/10.1111/j.1540-4781.2007.00674.x

Borg, S. (2006). Teacher cognition and language education: Research and practice. London, England: Continuum. https://doi.org/10.5040/9781474219983

Brown, P., \& Levinson, S. C. (1978). Universals in language usage: Politeness phenomena. In E. N. Goody (Ed.), Questions and politeness: Strategies in social interaction (pp. 56-289). Cambridge, England: Cambridge University Press.

Burden, P. (2001). When do native English speaking teachers and Japanese college students disagree about the use of Japanese in the English conversation classroom? The Language Teacher, 25(4), 5-9. Retrieved from http://jaltpublications.org/tlt/archive

Butzkamm, W. (2003). We only learn language once. The role of the mother tongue in FL classrooms: Death of a dogma. The Language Learning Journal, 28, 29-39. https://doi.org/10.1080/09571730385200181

Butzkamm, W., \& Caldwell, J. A. W. (2009). The bilingual reform: A paradigm shift in foreign language teaching. Tübingen, Germany: Gunter Narr Verlag.

Carless, D. (2007). Student use of the mother tongue in the task-based classroom. ELT Journal, 62, 331-338. https://doi.org/10.1093/elt/ccm090

Cohen, A. D. (2004). Assessing speech acts in a second language. In D. Boxer \& A. D. Cohen (Eds.), Studying speaking to inform second language learning (pp. 302-327). Clevedon, England: Multilingual Matters.

Donato, R. (1994). Collective scaffolding in second language learning. In J. P. Lantolf \& G. Appel (Eds.), Vygotskian approaches to second language research (pp. 33-56). Norwood, NJ: Ablex. 
Dörnyei, Z. (2007). Research methods in applied linguistics: Quantitative, qualitative and mixed methodologies. Oxford, England: Oxford University Press. https://doi.org/10.1017/s0272263110000094

Foster, P., \& Ohta, A. S. (2005). Negotiation for meaning and peer assistance in second language classrooms. Applied Linguistics, 26, 402-430. https://doi.org/10.1093/applin/ami014

Gass, S. M., \& Mackey, A. (2000). Stimulated recall methodology in second language research. Mahwah, NJ: Erlbaum. https://doi.org/10.4324/9781410606006

Ishihara, N., \& Cohen, A. D. (2010). Teaching and learning pragmatics: Where language and culture meet. Harlow, England: Pearson Education. https://doi.org/10.4324/9781315833842

Jin, L., \& Cortazzi, M. (2011). The changing landscapes of a journey: Educational metaphors in China. In J. Ryan (Ed.), Education reform in China: Changing concepts, contexts and practices (pp. 113-131). London, England: Routledge.

Keyes, C. (2000). The early childhood teacher's voice in the research community. International Journal of Early Years Education, 8, 3-13.

https://doi.org/10.1080/096697600111707

Kidd, J. A. (2016). Face and enactment of identities in the L2 classroom. Clevedon, England: Multilingual Matters.

Kobayashi, M. (2003). The role of peer support in ESL students' accomplishment of oral academic tasks. Canadian Modern Language Review, 59, 337-369. https://doi.org/10.3138/cmlr.59.3.337

Lantolf, J. P. (Ed.). (2000). Sociocultural theory and second language learning. Oxford, England: Oxford University Press.

Levine, G. S. (2003). Student and instructor beliefs and attitudes about target language use, first language use, and anxiety: Report of a questionnaire study. The Modern Language Journal, 87, 343-364. https://doi.org/10.1111/1540-4781.00194

Mackey, A., \& Gass, S. M. (2005). Second language research: Methodology and design. Mahwah, NJ: Erlbaum. https://doi.org/10.4324/9781410612564

Meyer, H. (2008). The pedagogical implications of L1 use in the L2 classroom. Maebashi Kyodai Gakuen College Ronsyu, 8, 147-159. Retrieved from http://www.kyoai.ac.jp/college/ronshuu/no-08/meyer1.pdf

Morita, N. (2000). Discourse socialization through oral classroom activities in a TESL graduate program. TESOL Quarterly, 34, 279-310. https://doi.org/10.2307/3587953 
Nakane, I. (2006). Silence and politeness in intercultural communication in university seminars. Journal of Pragmatics, 38, 1811-1835. https://doi.org/10.1016/j.pragma.2006.01.005

Nation, P. (2003). The role of the first language in foreign language learning. Asian EFL Journal, 5(2), 1-8. Retrieved from http://asian-efl-journal.com/

Norton, B. (2013). Identity and language learning: Extending the conversation (2nd ed.). Bristol, England: Multilingual Matters.

Norton, B., \& Toohey, K. (2002). Identity and language learning. In R. Kaplan (Ed.), The Oxford handbook of applied linguistics (pp. 115-123). Oxford, England: Oxford University Press.

Ohta, A. S. (2000). Rethinking interaction in SLA: Developmentally appropriate assistance in the zone of proximal development and the acquisition of L2 grammar. In J. Lantolf (Ed.), Sociocultural theory and second language learning (pp. 51-78). Oxford, England: Oxford University Press.

Plaut, S. (2006). 'I just don't get it': Teachers' and students' conceptions of confusion and implications for teaching and learning in the high school English classroom. Curriculum Inquiry, 36, 391-421. https://doi.org/10.1111/j.1467-873x.2006.00364.x

Sime, D. (2006). What do learners make of teachers' gestures in the language classroom? International Review of Applied Linguistics in Language Teaching, 44, 211-230. https://doi.org/10.1515/iral.2006.009

Stephens, M. (2006). The use and abuse of Japanese in the university English class. The Language Teacher, 30(8), 13-18. Retrieved from http://jalt-publications. org/tlt/archive

Swain, M. (2000). The output hypothesis and beyond: Mediating acquisition through collaborative dialogue. In J. Lantolf (Ed.), Sociocultural theory and second language learning (pp. 97-114). Oxford, England: Oxford University Press.

Swain, M., Brooks, L., \& Tocalli-Beller, A. (2002). Peer-peer dialogue as means of second language learning. Annual Review of Applied Linguistics, 22, 171-185. https://doi.org/10.1017/s0267190502000090

Swain, M., \& Lapkin, S. (2000). Task-based second language learning: The uses of the first language. Language Teaching Research, 4, 251-274. https://doi.org/10.1177/136216880000400304

Tani, M. (2008). Raising the in-class participation of Asian students through a writing tool. Higher Education Research and Development, 27, 345-356. https://doi.org/10.1080/07294360802406817 
Turnbull, M., \& Dailey-O'Cain, J. (Eds.). (2009). First language use in second and foreign language learning. Bristol, England: Multilingual Matters.

Yoshida, R. (2008). Learners' perception of corrective feedback in pair work. Foreign Language Annals, 41, 525-541. https://doi.org/10.1111/j.1944-9720.2008.tb03310.x 